\title{
Využitie filozofického textu v mimoškolských aktivitách v kontexte osobnostného a sociálneho rozvoja detí mladšieho školského veku ${ }^{1}$ Gabriela Šarníková
}

\begin{abstract}
Abstrakt:
Príspevok je zameraný na problematiku prierezovej témy Osobnostný a sociálny rozvoj v záujmovom krúžku detí mladšieho školského veku založenom na koncepcii filozofie pre deti. Predkladaný text je súčastou širšieho skúmania a je jedným z výsledkov úsilia priaznivcov tejto koncepcie implementovat' ju do procesu edukácie na Slovensku.

Cielom príspevku je opísat’ a analyzovat’ priebeh a výsledky kvalitatívneho výskumu realizovaného počas uvedeného krúžku. Zamerali sme sa na možnosti využitia filozofického textu pre deti a následnej diskusie v osobnostnom a sociálnom rozvoji.

Výsledky výskumu ukázali na vhodnost’ implementovania filozofie pre deti v súčinnosti s predmetnou prierezovou témou do tohto typu neformálneho vzdelávania, ako aj na vztah medzi diskusiou vychádzajúcou z textu a uvedenou prierezovou témou. Zároveň sa ukázali niektoré slabé stránky a rezervy využívania filozofického textu pre deti.
\end{abstract}

Klúčové slová: Osobnostný a sociálny rozvoj, filozofia pre deti, filozofický text, diskusia, záujmový krúžok

\section{Úvod}

Problematika čítania detí a s det’mi má viacero aspektov aj zámerov. Primárne súvisí čítanie (umeleckej) literatúry s rozvojom estetického cítenia a zmyslu pre krásu či utváraním vkusu, ${ }^{2} s$ čím súvisí aj emocionálny rozvoj. Čítanie literatúry vplýva na rozvoj fantázie, podporuje obohacovanie slovnej zásoby aj komunikačné zručnosti a kognitívny rozvoj. Literárny text, resp. prácu s ním možno zamerat aj na formovanie kritického myslenia, ale aj na osobnostný a sociálny rozvoj.

Jedným z druhov literatúry je text písaný na filozofické diskutovanie s detmi, ktorého primárnym cielom je rozvoj kritického, kreatívneho a angažovaného myslenia, ale zohladňuje sa aj sociálny a etický aspekt. Čítanie filozofických príbehov pre deti má miesto jednak vo formálnom, ale rovnako aj v neformálnom vzdelávaní. 


\section{Teoretické východiská}

Filozofický text, resp. filozofické romány pre deti sú špecifickým literárnym druhom so špecifickým zámerom.

Prvé romány písal zakladatel' koncepcie filozofie pre deti (d’alej FPD) Matthew Lipman. Hladal spôsob, ako pomôct' detom v rozvoji myslenia, a uvážil, že vhodným prostriedkom je literatúra. Kládol si otázku, aký typ literatúry je vhodný. Dospel k záveru, že by to mali byt príbehy blízke detom z viacerých aspektov: „Malo by to byt niečo, čo by mladí ludia s malou pomocou dospelých objavili sami. Hrdinovia príbehov by mali vytvárat malé bádatelské skupiny, v ktorých by sa každé $z$ nich do istej miery aspoň trochu podielalo na spoločnom hladaní a objavovaní efektívnejších spôsobov myslenia... aby malá skupina detí v príbehu mohla poslúžit ako vzor, s ktorým sa skutočné deti v triede budú môct' identifikovat. Akýsi portrét detí žijúcich spolu rozumne a so vzájomným rešpektom, dávajúci detom nádej, že takýto ideál je uskutočnitelný. “”

Takýto text a jeho čítanie v skupine sa stal v uvedenej koncepcii východiskom pre následnú diskusiu skupiny detí, ktorú Lipman nazval hladajúcim (pátrajúcim či bádajúcim) spoločenstvom (community of inquiry). Jeho členovia spoločne usilujú o hladanie odpovedí na stanovené otázky a problémy, lebo nie „parta“, ale blízki ludia dokážu bez obáv z ohrozenia hovorit o tom, že niečomu nerozumejú. ${ }^{4}$

Diskusia má prieniky so sokratovským dialógom, no nezačína sa analýzou pojmu (táto čast’ býva súčastou klarifikácie otázky ešte pred samotnou diskusiou), aj ked’ proces definície pojmov býva jej súčastou. Téma diskusie (otázka) sa najčastejšie formuluje po prečítaní literárneho textu - filozofického príbehu tvoreného na FPD.

Práca s filozofickým textom pre deti a následná diskusia sa explicitne javí ako jeden z najlepších spôsobov rozvoja kritického myslenia, ktorého problematika je v súčasnosti aktuálna nielen $\mathrm{v}$ krajinách Európy, ale aj $\mathrm{v}$ zemiach $\mathrm{s}$ iným kultúrnym a náboženským zázemím ${ }^{5}$. Úzko súvisí s rozvojom čitatel'skej gramotnosti (rovnako aj v medzinárodnom meradle), ktorá vyjadruje požadované základné schopnosti človeka v prijímaní a spracovaní informácií z textu a ich sociálno-kultúrne ukotvenie. ${ }^{6}$

FPD má spresňovat’ a prehlbovat také myslenie, ktoré ulahčuje rozhodnutia, ide teda o podporu rozvoja kritického myslenia, ktoré Lipman charakterizuje ako myslenie pomáhajúce tvorbe úsudkov, pretože sa opiera o kritériá, je sebakorektívne a vnímavé na kontext.7 Lipman však nezostáva iba pri tejto úrovni. Uvádza, že ide o rozvoj mulidimenzionálneho myslenia, ktoré smeruje k rovnováhe medzi rozumom a afektivitou, medzi vnímaním a tvorením pojmov, medzi telesnostou a psychikou, medzi tým, čo je ovládané pravidlami, a tým, čo pravidlá neovládajú. Je to prienik myslenia kritického, kreatívneho a angažovaného. Kritické myslenie hladá dôvody (príčinné aj účelové), pracuje s obsahom a rozsahom pojmu, so súdmi, úsudkami, definíciami... Má zabránit’

3 Matthew LIPMAN, On Writing a Philosophical Novel, in: Studies in Philosophy for Children. Harry Stottlemeier's Discovery, ed. Ann Margaret SHARP - Ronald F. REED, Philadelphia: Temple University Press, 1992, s. 21.

4 Porov. Matthew LIPMAN - Ann Margaret SHARP - Frederick S. OSCANYAN, Philosophy in the Classroom, Philadelphia: Temple University Press, 1980.

5 Porov. (c) Sozan H. OMAR, Mastery Level of Critical Thinking Skills for Female Middle School Students in Saudi Arabia, Journal of Educational \&́ Psychological Sciences 19/4, 2018, s. 230-258 (online), dostupné na: https://journal.uob.edu.bh/bitstream/ handle/123456789/3441/8.pdf?sequence=1\&isAllowed=y, citováno dne 15. 11. 2019.

6 Porov. Mária LALINSKÁ - Eva STRANOVSKÁ - Zdenka GADUŠOVÁ, Instruments for Testing Reading Comprehension, IRCEELT 2019: Proceedings book from the $9^{\text {th }}$ International Research Conference on Education, Language and Literature, ed. Natela DOGHONADZE, Tbilisi: International Black Sea University, 2019, s. 249.

7 Podobne, ako sa v európskom kontexte hovorí o kompetenciách a klúčových kompetenciách, M. Lipman uvádza, že je nevyhnutné získat počas výchovno-vyučovacieho procesu aj niekolko typov zručností a jedným z nich sú zručnosti v uvažovaní - „the thinking skills“. 
rýchlemu zovšeobecňovaniu a tvorbe predsudkov. Vychádza z aristotelovskej logiky a je nástrojom aj odrazovým mostíkom pre dalšie dva typy myslenia. Vlastnostami kreatívneho myslenia sú originalita, produktivita, predstavivost', fantázia, nezávislost', experimentovanie, expresivita, sebaprekročenie, vynaliezavost', celistvost’ a pod. Angažované myslenie si vyžaduje účast' citovej sféry, zaujatost pre problém, vášeň pri riešení problému, empatiu. Je to afektívne a normatívne myslenie. V praxi sa tieto tri druhy myslenia nedajú oddelit, ide len o metodické delenie.

Vo FPD je evidentný sociálny a etický rozmer. Jednak sa v príbehoch riešia otázky súvisiace s uvedenými dvoma rovinami života a jednako sa diskusia samotná týka etického aj sociálneho aspektu $\mathrm{v}$ realite skupiny.

V súčasnej slovenskej (aj českej) edukácii je etický a sociálny rozvoj problematikou, ktorá je včlenená najmä do prierezovej témy Osobnostný a sociálny rozvoj (v Českej republike Osobnostná a sociálna výchova). Štátny vzdelávací program umožňuje zaviest prierezovú tému do výučby ako samostatný vyučovací predmet, zväčša sa však jej obsah a ciele realizujú naprieč predmetom. Obe formy sa však môžu kombinovat. Správna realizácia prierezovej témy má prispiet k pozitívnej sociálnej klíme školy a k dobrým vztahom.

Zároveň ide o tému, ktorá je $\mathrm{v}$ súčasnosti úzko prepojená s požiadavkami kladenými na rozvoj špecifických profesijných kompetencií učitelov zameraných na faktory učenia sa s účinkom na individualitu a rozvíjanie osobnosti žiaka. ${ }^{8}$

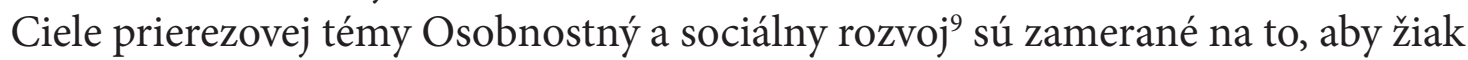

- porozumel sebe a iným;

- optimálne usmerňoval vlastné správanie a prejavovanie emócií;

- uprednostňoval priatel'ské vztahy v triede i mimo nej;

- osvojil si, využíval a d’alej rozvijal zručnosti komunikácie a vzájomnej spolupráce;

- nadobudol základné prezentačné zručnosti osvojené na základe postupného spoznania svojich predpokladov a uplatñoval ich pri prezentácii seba a svojej práce;

- ziskal a uplatňoval základné sociálne zručnosti pre optimálne riešenie rôznych situácií;

- rešpektoval rôzne typy ludí, ich názory a prístupy k riešeniu problémov;

- uprednostňoval základné princípy zdravého životného štýlu a nerizikového správania vo svojom živote. ${ }^{10}$

Aj ked’ sú prierezové témy zakotvené vo vzdelávacích programoch, „účinnost ich pôsobenia sa môže zvýšit relevantnými mimoškolskými aktivitami “. ${ }^{11}$ Tento aspekt sme využili počas záujmového krúžku, ktorý sme viedli s deṫmi mladšieho školského veku. Krúžková činnost', ako aj činnost školských zariadení sa na Slovensku riadi výchovným programom toho-ktorého zariadenia, pričom si ho tvorí každé zariadenie nezávisle od iného. Existuje len odporúčaný, no nie záväzný obsah, a tak myšlienky a námety témy Osobnostný a sociálny rozvoj možno implikovat do mimoškolských aktivít s cielom nenásilného a prirodzeného osvojovania komunikačných a iných mäkkých či interpersonálnych zručností (uvádzaných aj ako soft skills), etického správania a emocionálneho aj spirituálneho rozvoja.

8 Porov. Mária LALINSKÁ - Eva STRANOVSKÁ, Proposal for a Reference Framework and Tools for the Evaluation of Teachers Professional Competences in Slovakia, International Journal of Economic Research 2/2018, s. 289-298.

9 Porovnatelne sú formulované aj ciele prierezovej témy Osobnostní a sociální výchova v kurikule v Českej republike.

10 C Štátny vzdelávací program - primárne vzdelávanie (online), dostupné na: http://www.statpedu.sk/files/articles/dokumenty/ inovovany-statny-vzdelavaci-program/svp_pv_2015.pdf, citováno dne 18. 3.2019, s. 11.

11 (c) Štátny ..., s. 10. 
Skĺbenie čítania filozofických románov a následnej diskusie počas záujmového krúžku sa ukázalo ako vhodné na napíňanie cielov predmetnej prierezovej témy.

„Čitatelstvo ako výraz osobnostného zamerania na určitý druh receptívnej činnosti (na čítanie) sa vo svojej kvantite a kvalite premieta do celkového spôsobu správania a konania človeka vo všetkých jeho rolách", ${ }^{12}$ a tak nás z výskumného hladiska zaujímalo, aký je vztah medzi filozofickým textom pre deti, resp. procesom čítania, recepciou a pochopením jeho obsahu a následnou diskusiou na jednej strane a ich osobnostným a sociálnym rozvojom na strane druhej.

\section{Empirická čast’}

V čase realizácie krúžku aj počas empirického skúmania sa na Slovensku usilovalo niekol'ko prívržencov FPD o jej sprostredkovanie pedagogickej verejnosti. Výsledky snáh o rozšírenie povedomia o tejto koncepcii sú viditelné najmä v akademickom prostredí na univerzitách $\mathrm{v}$ Nitre, Ružomberku, Banskej Bystrici a v Bratislave, čoho výsledkom je (pomerne málo zastúpená) publikačná činnost a príspevky na konferenciách, ale aj napríklad zavedenie nepovinného predmetu filozofia pre deti na ružomberskej univerzite pre študentov predškolského a primárneho vzdelávania či letná škola organizovaná PdF UMB v Banskej Bystrici. Koncepcia FPD ani texty, ktoré sa v nej využívajú, však stále nie sú známe pedagógom v predškolskom a školskom vzdelávaní. Jedným z krokov k implementácii je zavedenie krúžku založenom na tejto koncepcii na základnej škole v meste na strednom Slovensku. V rovnakom čase neexistovali ani výskumy v oblasti realizovania prierezových tém na základných a stredných školách.

\section{Ciel'výskumu}

Cielom skúmania bolo zistit a opísat, ako možno v mimoškolských aktivitách využit filozofický text pre deti na ich rozvoj v kontexte prierezovej témy Osobnostný a sociálny rozvoj.

$\mathrm{K}$ špecifickým cielom sme zaradili skúmanie postojov, prežívania a správania participantov po prečítaní textu a následnej diskusii v kontexte osobnostného a sociálneho rozvoja.

\section{Výskumné otázky}

Vzhladom na to, že sme zvolili kvalitatívne skúmanie, ktorého povaha je cirkulárna, problematika formulácie výskumných otázok sa modifikovala, resp. reformulovali sme ich ${ }^{13}$ adekvátne vynárajúcim sa témam/kategóriám $\mathrm{v}$ transkriptoch diskusií počas prvotných analýz. Významným aspektom (vzhladom na vynárajúce sa témy) sa ukázalo sledovanie kognitívnej, emocionálnej a behaviorálnej stránky detí počas fungovania krúžku, čo sa stalo aj súčastou otázok.

V súčinnosti s výskumným cielom sme sformulovali tieto výskumné otázky:

1. Aký postoj zaujmú participanti k otázkam viažucim sa na ich osobnostný a sociálny rozvoj po prečítaní literárneho textu a v priebehu nasledujúcej diskusie?

2. Ako ovplyvňuje obsah prečítaného literárneho textu a následná diskusia $\mathrm{k}$ nemu osobnostný a sociálny rozvoj participantov?

12 Kateřina HOMOLOVÁ, Dospívající mládež a dvě hodnoty čtenářství, in: Mládež, hodnoty a volný čas, ed. Helena POSPÍŠILOVÁ, Olomouc: Hanex, 2010, s. 94.

13 Porov. Roman ŠVAŘÍČEK - Klára ŠEĎOVÁ a kol., Kvalitativní výzkum v pedagogických vědách, Praha: Portál, 2007, s. 69. 
3. Aký druh literatúry, resp. text na diskutovanie navrhujú participanti sami, ked' berieme do úvahy aspekt osobnostného a sociálneho rozvoja?

\section{Výskumná vzorka}

Výskumnú vzorku tvorili dve skupiny žiakov mladšieho školského veku cirkevnej základnej školy v okresnom meste (do 30000 obyvatelov) na strednom Slovensku. Z výskumného hladiska nás deti zaujímajú ako jedna skupina, $\mathrm{z}$ formálneho hladiska (vzhladom na kódovanie textu), sme skupinu z prvého roka označili ako A a druhú ako B. Prvá skupina žiakov absolvovala krúžok v jednom školskom roku a druhá skupina v d’alšom (2013/2014 a 2014/2015). V skupine A bolo osem žiakov štvrtákov a skupinu B tvorilo devät žiakov, z toho štyria štvrtáci a pät piatakov. Pre výsledky našej štúdie sme žiakov piateho ročníka neeliminovali, pretože vekové rozdiely participantov neboli relevantné.

\section{Typ výskumu a použité metódy}

Na splnenie stanoveného ciela a pri hladaní odpovedí na formulované otázky sme zvolili kvalitatívny aplikovaný výskum. Kedže sme si všímali len isté fenomény v ponímaní a prežívaní participantov, zvolili sme interpretatívnu fenomenologickú analýzu (IPA). ${ }^{14}$

Základnou metódou bol dialóg - jednak rozhovory a jednak diskusie. Okrem týchto dvoch metód sme využívali aj tvorivé aktivity participantov, ale vzhladom na ciele tohto príspevku ich eliminujeme.

\section{Priebeh výskumu}

Výskum sa začal zavedením záujmového krúžku. Jeho obsah a priebeh korešpondovali s koncepciou FPD.

Uskutočnilo sa 28 stretnutí, väčšina z nich mala klasickú štruktúru, ako sa realizuje vo FPD: začalo sa čítaním textu (v závislosti od jazyka ho čítala výskumníčka alebo participanti), ak bolo potrebné, participanti kládli otázky súvisiace s neporozumením niektorých slov. Nasledovala formulácia otázok na diskusiu. Ide o typ otázok podobný sokratovským, ${ }^{15}$ no kladú ich deti, nie pedagóg (ten v procese diskutovania zastáva úlohu facilitátora či koordinátora), ${ }^{16}$ proces ich tvorby má svoje kritériá a rovnako aj ich využitie má vo FPD svoje špecifiká. ${ }^{17}$

Počas krúžku si deti mohli zvolit, či chcú otázky tvorit’ samy, alebo vo dvojici či trojici. Sformulované otázky písali na tabulu. Ked’ boli otázky napísané, tvorcovia ich ešte raz prečítali a vysvetlili ostatným, na ktorú čast’ prečítaného textu otázka reaguje a čo otázka znamená. Práve v tejto časti sa realizovala už spomenutá klarifikácia niektorých slov, prípadné preformulovanie alebo

14 Porov. John W. CRESWELL, Qualitative Inquiry \& Research Design. Choosing among Five Approaches, London: Sage, 2013, s. 77-83; taktiež Jonathan A. SMITH - Paul FLOWERS - Michael LARKIN, Interpretative Fenomenological Analysis. Theory, Method and Research, London: Sage, 2013.

15 Porov. (C) MiYoung LEE - Hyewon KIM - Minjeong, KIM, The effects of Socratic questioning on critical thinking in web-based collaborative learning (on-line), in: Education as Change, 2/2014, s. 285-302, dostupné na: https://www-tandfonline-com.proxy-ub.rug. nl/doi/full/10.1080/16823206.2013.849576, citováno dne 20. 1. 2020.

$16 \mathrm{Na}$ druhej strane problematika sokratovskej otázky či sokratovského dialógu nie je v pedagogike jednoznačne zadefinovaná. Pri ich charakteristike sa berú do úvahy rôzni autori rôzne aspekty (porov. () Josef PETRŽELKA, Sókratovská metoda na internetu, (online), in: Pro-Fil. an Internet Journal of Philosophy, 1/2000, dostupné na: https://www.phil.muni.cz/journals/index.php/profil/article/ view/1509/1782, citováno dne 22. 6. 2020).

17 Porov. Eva ZOLLER, Učíme děti ptát se a přemýšlet. Praha: Portál, 2012. 
zlúčenie otázok, ak boli takmer zhodné. ${ }^{18}$

Priebeh pokračoval po úprave a vysvetlení otázok hlasovaním - volbou jednej z nich podla najvyššieho počtu hlasov. Ak bol dostatok času diskutovalo sa aj o dalších otázkach v poradí podla priradeného počtu bodov.

Od samého začiatku platili na krúžku isté pravidlá, ktoré participanti sami formulovali. Jedným bolo to, že hovorí iba ten, kto požiada o slovo dohodnutým spôsobom, teda že si neskáčeme do reči, iným, že sa nebudú používat nadávky alebo vulgárne slová, že sa budeme počúvat a nebudeme vyrušovat' a pod. Pre samotný proces diskusie platilo, že budeme používat príklady na svoje tvrdenia, popr. protipríklady, že budeme klást’ d’alšie otázky, že budeme na seba reagovat', že nebudeme odbočovat' od témy a pod.

Po každej diskusii nasledovala reflexia. Jednak participanti hodnotili, aké otázky kládli, kto na koho nadväzoval, kto použil príklad, kto protipríklad, kto definoval slovo/pojem, ktorá otázka alebo odpoved' či reakcia smerovala na angažovanost' detí, kto urobil nejaký záver (syntézu), či sa odbočilo od témy/otázky, kto na to upozornil a pod.

Na záver diskusie alebo krúžku participanti hodnotili priebeh, rešpektovanie pravidiel, vyjadrovali svoje prežívanie či postoje vzhladom na aktivity počas krúžku.

Všetky aktivity boli zaznamenané na videozáznam, na základe ktorého sa tvorili výskumné dáta vychádzajúce $z$ transkriptov a vlastných poznámok k priebehu krúžku aj k práci s transkriptom. Na výskumné účely sme v transkripte zmenili všetky mená (aj ich podoby) detí s cielom zaručit anonymitu. Nasledoval proces kódovania a následne saturovanie vynárajúcich sa tém. Každý riadok transkriptu sme očíslovali a vynárajúce sa témy sme značili farebne. Následne sme vedla transkriptu utvorili nový stĺpec, do ktorého sme písali už len farebne vyznačené slová alebo slovné spojenia. Následne sme utvorili další stĺpec obsahujúci analýzu a v dalšom stl̂pci sme písali vlastné poznámky zamerané jednak na kontext, postupnost’ rozvíjania tém, ale aj na súvislosti medzi vynárajúcimi sa témami, ako aj poznámky týkajúce sa konkrétnych jednotlivcov.

Text sme čítali niekol'kokrát a začali sme sledovat’ aj vertikálnu líniu. Utvorili sme novú úroveň kódovania $\mathrm{v}$ podobe nových kategórií, ktorým sme prirad’ovali už utvorené témy. Počet kategórií sa v porovnaní s témami zredukoval, kategórie sme nasycovali počas d’alšieho čítania.

V dalšom kroku sme využili program NVivo 10. K tomuto kroku nás viedlo zistenie, že mnoho textu - výpovedí detí možno zaradit do viacerých kategórií. Takéto spracovanie nám umožnilo hladanie spoločných tém naprieč skúmaným transkriptom. Kategórie, ktoré sme utvorili, boli napríklad emócie so subkategóriou - kognícia (ked' deti o emóciách alebo prežívaní hovorili) a behaviorálna zložka (zaznamenávali sme prejavy emócií) a ešte nižšou kategóriou bola klasifikácia emócií. Inou kategóriou bola verbálna komunikácia, ktorú sme sledovali z lingvistického hladiska, teda patrili sem subkategórie ako spisovné a nespisovné slová, nadávky, citoslovcia, otázky a pod. Ďalšou kategóriou bolo kritické myslenie a subkategóriami boli napr. otázky (toto je príklad, ked' sa jedna téma dostala do dvoch kategórií), definície, argumenty, príklady, protipríklady a pod). Inou kategóriou bola napr. škola, jej subkategórie - postoje k škole, učitel', skúšanie, hodnotenie, spolužiaci... Ďalšia kategória obsahovala témy súvisiace so vztahmi atd’.

Po ukončení kategorizácie a saturácie všetkých tém sme získali množstvo dát, ktoré sa stali základom pre tvorbu nových výskumných problémov a otázok. Jedným z nich bol vztah medzi čítaným

18 Považujeme za potrebné podotknút, že formulácia otázok na diskutovanie robila spočiatku detom problémy. Otázky boli bud' zatvorené, alebo mali takú formuláciu, že odpoved’ bola explicitná na základe textu (išlo predovšetkým o otázky na zapamätanie), resp. tvorcovia otázok poznali odpovede a chceli poznat odpovede ostatných. Bolo potrebné uvádzat príklady na otázky vychádzajúce z textu a zároveň nabádajúce k diskusiu. Aktívna účast pedagóga bola v tomto prípade nevyhnutnostou. Asi po mesiaci však už deti dokázali formulovat otázky rozvíjajúce dialóg, resp. diskusiu a samy vedeli zhodnotit', aký typ otázky sformulovali. 
textom a sociálnym a osobnostným aspektom, teda témou predkladaného príspevku. Vzhladom na základnú výskumnú otázku sme sledovali aj obohacujúce a osvetlujúce témy. ${ }^{19}$ Do procesu analýzy sme vybrali tie, ktoré sa vzt’ahujú na výskumné otázky.

\section{Využité literárne texty}

Čítali sme texty priamo určené na filozofické diskutovanie, ale v priebehu krúžku sme sa rozhodli využit aj inú literatúru v zhode s názormi iných priaznivcov FPD.

Napriek tomu, že literatúra z oblasti FPD nevyšla v slovenskom preklade a doteraz nebola vydaná ani pôvodná slovenská tvorba s uvedeným zámerom, rozhodli sme sa čítat jednak české preklady a jednak sme na účely krúžku využili aj slovenské preklady českých textov. Český text čítala výskumníčka, slovenské texty čítali participanti. Čítali sa knihy Blanka a Jirka ${ }^{20}$ a Lukáš a Lenka ${ }^{21}$ od P. Laurendeaua, príbehy z románu Elišk $a^{22}$ od M. Lipmana. Ďalším textom bola Hitlerova dcéra ${ }^{23}$ od J. Frenchovej. Kniha nie je explicitne určená na FPD, ale obsah a spôsob napísania zodpovedá filozofickým románom pre deti. Kniha vyšla v českom preklade, ale na potreby krúžku sme text preložili do slovenčiny.

Okrem tejto literatúry sme využili aj knihy preložené do slovenčiny, ktoré primárne nie sú určené na FPD, ale vzhladom na obsah a zameranie textov sa javili ako vhodné a zo skúsenosti sme vedeli, že deti tieto knihy rady čítajú. Išlo i príbehy žabiakov Kvaka a Člupa (v origináli Frog and Tod) od A. Lobela ${ }^{24}$.

Iným zdrojom boli príbehy zajaca Priesemuta a žabiaka Nulliho od M. Sodtkeho ${ }^{25}$ a rozprávka o odvahe od L. Pauliho ${ }^{26}$. Tieto príbehy sú v nemčine, preto sme pristúpili k možnosti pracovat s textom preloženým do slovenčiny len na účely krúžku. Participanti dostali slovenský vytlačený text a knihy s originálnym nemeckým textom boli na zemi uprostred kruhu diskutujúceho spoločenstva. Uvedené tituly sa využívajú pri realizácii FPD v nemecky hovoriacich krajinách.

Ďalší text, ktorý sme použili, bol krokom, s ktorým sme viac-menej experimentovali.

Išlo o detektívne príbehy s otvoreným koncom od H. Conrada (2006) Kdo je pachatel?27 Ani tieto knihy nevyšli v slovenskom preklade, no po skúsenosti s čítaním českého textu filozofických románov sme využili čítanie v češtine, s čím participanti nemali problém.

Výber iného textu súvisí s tým, že M. Lipman povzbudzoval prívržencov FPD, aby modifikovali už napísané (a preložené texty) vzhladom na kultúrny kontext a aby sami príbehy tvorili, ako aj s tým, že v súčasnosti sa objavujú výzvy siahnut aj po iných textoch, ak sa javia, že by práca s nimi mohla naplñat’ ciele FPD. ${ }^{28}$

19 Porov. SMITH - FLOWERS - LARKIN, Interpretative..., s. 79-103.

20 Porov. Pierre LAURENDEAU, Blanka a Jirka, České Budějovice: TF JU, Centrum filozofie pro děti, 2011.

21 Porov. Pierre LAURENDEAU, Lukáš a Lenka, České Budějovice: TF JU, Centrum filozofie pro děti, 2011.

22 Porov. Matthew LIPMAN, Eliška, České Budějovice: TF JU, Centrum filozofie pro děti, 2012.

23 Porov. Jackie FRENCHOVÁ, Hitlerova dcera, Praha: Mladá fronta, 2009.

24 Porov. Arnold LOBEL, Kvak a Člup sú kamaráti, Prešov: Slniečkovo, 2008.

25 Porov. Matthias SODTKE, Gibt es eigentlich Brummer, die nach Möhren schmecken? Oldenburg: Lappan, 2011.

26 Porov. Lorenz PAULI, Mutig, mutig, Zürich: Atlantis, 2006.

27 Porov. Hy CONRAD, Kdo je pachatel? Praha: Portál, 2006.

28 Porov. Lenka MACKU゚, Filozofický rozměr literárního príběhu: uplatnění literárního příběhu v programu Filozofie pro děti,. České Budějovice, 2010. Diplomová práce, Jihočeská univerzita v Českých Budějovicích, Teologická fakulta, vedoucí práce doc. Ludmila Muchová, s. 48. 


\section{Tematické analýzy}

V analýzach uvádzame len vybraté časti súvisiace s predmetnou problematikou.

Prvou výskumnou otázkou Akýpostoj zaujmú participanti k otázkam viažucim sa na ich osobnostný a sociálny rozvoj po prečítaní literárneho textu a v priebehu nasledujúcej diskusie? sme sledovali tie vyjadrenia a reakcie participantov, ktoré sú spojené s osobnostným a sociálnym rozvojom (dalej OSR). Zamerali sme sa na kognitívny a emocionálny aspekt. Zaujímali nás reflexie, charakteristiky, argumentácie, reakcie a pod. V procese kódovania a kategorizácie sa objavili témy, ktoré sme mohli zaradit aj do cielov OSR: porozumenie sebe a iným, osvojovanie a využívanie zručnosti komunikácie a spolupráce, uplatňovanie sociálnych zručností pre riešenie problémov.

Po prečitaní príbehu o Kvakovi a Člupovi sa rozvinula diskusia na otázku, či je rozdiel medzi spachtošom a lenivcom, po prečítaní príbehu Odvaha, odvaha deti diskutovali o otázke Prečo niektorí robia nerozumné veci? Texty sa detí dotkli osobne, porovnávali sa s postavami, ale vyjadrovali aj svoje túžby aj obavy. V mnohých výrokoch sa odzrkadlovalo ich vlastné správanie, ktoré sa $z$ istého aspektu prejavovalo aj na krúžku. Participant, ktorý sa inokedy počas krúžku vyjadroval $\mathrm{k}$ téme učenia, že sa nerád učí, že sa mu nechce učit, pri tejto téme povedal, že spachtoš znamená, že „nič nerobí, že iba leží (A2929), participant, ktorý hovorieval, že sa rád hrá s autodráhou, sa k spachtošovi vyjadril, že je to „ten kto vstáva len cez ovládač“ (A2941). Lenivec je podla participanta ten, čo „nepohne ani prstom“ (A2965). Iný o sebe povedal: „Tak ja som lenivý a vstanem z postele, ale ked'vstanem z postele, tak už sa premôžem “(A2891), na to participantka zareagovala, že „to nemôže, potom nie je lenivý“ (A2904).

Pri téme Odvaha participant zareagoval: „Ja by som sa bál skočit do vody“ (B2182).

Po prečítaní príbehu z Hitlerovej dcéry sa diskutovalo na otázku či sme na niektoré veci malí a na niektoré velkí. Hovorili o sebe, vyjadrovali sa úprimne a reálne, tak ako sa vnímajú a v akej realite žijú. Očakávali sme, že pri téme čítania rozprávok sa už budú považovat za vel'kých, no pohlad participantov na seba bol iný, ako náš predpoklad. Participant uviedol, že na čítanie rozprávok nie je malý, lebo „...napríklad máš bračeka maličkého, jemu budeš rozprávat uspávanku alebo rozprávku“ (A6508). Iný nie je malý na čítanie rozprávok, lebo „deti majú väčšiu predstavivost̉ ako dospelí“ (A6547), iný zareagoval, že „,nie sme na to malí, lebo už vieme čítat“ (A6560).

Aj odpovede na to, či sú malí na šoférovanie auta nás prekvapili, pretože sme očakávali jednoznačné áno. $\mathrm{V}$ odpovediach detí sa prejavili aj vlastné skúsenosti, ktoré zažili v domácom prostredí: „Áno, sme na to malí, ale môžeme šoférovat“ (A 6750). „Sme aj tak malí, a ak tak, tak iba s niekým, ja som kamiónovala s otcom, bol pri mne oco. Malé auto môžeme“ (A6756).

Aj v otázke zameranej na to, či sú malí na to, aby chodili sami do školy, sa prejavila ich vlastná skúsenost: „Ja by som šiel aj sám, len mamina ma vozí, lebo ona tu pri škole robi“ (A6799). „Lebo už mám 9 rokov a mamina mi od tretej triedy dovolila íst samému, samému.“ „Nie sme na to malí, lebo už vieme sa - no vieme dávat pozor na to, či ide auto, alebo nie. No vieme proste, ako íst" (A6831). Po prečítaní textu knihy Blanka a Jirka zaznela otázka a následné reakcie: „Čo znamená, že ludia sú rovnakí, a predsa nie sú rovnakí?" Otázka bola takmer identická s textom, ktorý sa čítal, a participant, ktorý otázku položil, do nej vložil vel'kú nespokojnost:" „Ale jak to môže byt', že ludia sú rovnakí, aj ked’ nie sú rovnakí, to nedáva zmysel.“ Táto otázka rozprúdila vel’mi živú diskusiu, deti často uvádzali príklady z vlastnej skúsenosti: „To dáva zmysel, lebo ak niekto nemá rád niečo a iný má rád..." „No ale ja som mal tak, že ludia sú rovnakí aj nie sú rovnakí, a to môže byt̉ ako sú, ked nie sú?““ (B3942-3952). „Tak ja mám spolužiaka a spolužiačku dvojičky. A oni nie sú takí istí, ani vlasy, ani oblečenie, ani tvar tela. Oni sa v tom istom dni a týždni a mesiaci narodili. No sú rovnakí, lebo sa narodili, teda sú rovnakí v tom, že sa narodili v ten istý deň, ale nie sú rovnakí 
v iných veciach“(B4021-4025). Aj ked’ sme vedeli, že väčšina detí je z krestanských rodín, pri tejto otázke sme nečakali, že použijú ako argument poznatok z náboženstva: „Boh nás všetkých stvoril ako ludí, to akože sme rovnakí, ale my nie sme rovnakí, lebo sme každý iný“ (B4068-4070).

Pri téme o tom, že Hitler izoloval ludí, sa rozvinula diskusia na otázku, koho a prečo ludia izolujú: „Izolujeme chorých od zdravých, aby sa nenakazili tí zdraví a neboli aj oni izolovaní, a izolujeme aj teplo od zimy“ (A9351-9354). „Psychicky chorých izolujeme, aby si neubližili““(A9386). „Deti treba izolovat od počítača, ked’ sa nad ním zbláznia“ (A9417).

S prvou otázkou je spojený aj ciel OSR rozvoj základných komunikačných zručností a s ním je spojená problematika argumentácie, ktorá sa počas krúžku objavila dostatočne.

V Hitlerovej dcére zaujala deti otázka hry, ktorú sa literárne postavy hrali. Participantov téma hry zaujala a bola sformulovaná otázka, či všetko, čo robíme, môže byt hrou. Predpokladali sme, že deti budú mat jasne rozlíšené, čo je hra a čo nie je hra, no počas diskusie sa ukázalo, že hru spájajú so zábavou, a teda činnost', ktorá je zábavná, je hrou. Na otázku, či je chodenie do školy hra, participant zareagoval: „Áno, ked’ sa tešišš, že sa tam s niekým hrášs." Iný dodal: „Alebo rozprávaš,“ na čo participant zareagoval: „Ale do školy sa nikdy netešišs“ a participantka zareagovala: „Ked” je tam kamarátka spolužiačka, tak sa tešíšs (A7637-A7642). Ďalšia odpoved’ bola: „Informatika je v podstate hranie,“ ale reakcia: „Není to hranie, ... lebo tam sa aj učíme niečo“(A7675-7686). Na otázku, či proces učenia sa v škole nemôže byt hrou, participanti odpovedali: „Môže,“ ale zaznela aj odpoved” nie, pretože „každého určite nebaví tá škola“(A7723-7727). Z tohto uhla pohladu - že všetko, čo nás baví, dokázal participant vyvodit záver, že: „Všetko môže byt’ hrou. Ale nemyslím také veci, ako vojna, myslím také normálne, že všetko musí byt ako hra (A8015-8016).

Do prvej výskumnej otázky sme zahrnuli aj problematiku zameranú na sociálne zručnosti zamerané na riešenie rôznych situácií. Rozvoj tejto zručnosti dostával priestor po čítaní textov z detektívnych príbehov. Jedna $\mathrm{z}$ otázok bola, či máme púštat cudzích ludí do bytu a ako riešit, ked povedia, že potrebujú pomoc. Deti sú z rodín aj zo školy ponaučené, že cudzích ludí nepúštame do bytu a takéto odpovede aj prezentovali: „Podla mňa nepúštame takých, čo nepoznáme, by sme nemali hocikedy púštatt.“ „Pretože nevieme, že čoho sú schopní!“ Diskusia však priviedla participanta aj k otázke: „A ked' by prišiel nejaký zranený človek z ulice, ktorého nepoznáme, úplne teda taký nejaký, že zranený?" Ostatní zostali pri svojom tvrdení a hladali argumenty, ako ho obhájit: „Nie, by som dostal od neho chorobu.“ „Hm. Tak by som zavolal záchranku a počkal by som. Nechal by som ho vonku“" (B33513-33569).

Druhá výskumná otázka sa viaže na problematiku prežívania a správania po prečítaní textov a následnej diskusii. Zaujímalo nás, ako ovplyvňuje obsah prečítaného literárneho textu a následná diskusia osobnostný a sociálny rozvoj participantov z hladiska emocionálneho a behaviorálneho. Jedným z cielov prierezovej témy, ktorý sa viaže na túto otázku, je usmerňovanie vlastného správania a emócií. Častou témou po čítaní bola otázka pravidiel - jednak tých, ktoré sa spoločne sformulovali na krúžku a jednak pravidiel, o ktorých sa hovorilo v čítanom texte.

V príbehu o Hitlerovej dcére sa uvádza, že platili isté pravidlá. Jednou z otázok do diskusie bolo, aké by to bolo, keby neexistovali pravidlá. Participanti reagovali rôzne, javilo sa, že odpovedajú na základe vlastného prežívania, predovšetkým vnímania zákazov a nariadení: „Bolo by to super!“ (A28136), participantka však zareagovala: „Bez pravidiel by to bolo hrozné“ (A8144). Vnímali sme, že deti, ktoré mali v škole problémy so správaním, spontánne reagovali proti pravidlám, a tí, ktorí boli v škole dobrými žiakmi, sa pravidiel zastávali. Počas diskusie sa však zhodli na tom, že pravidlá musia byt', aby sme mohli normálne spolu žit'. 
Na kognitívnej úrovni participanti prejavili znalosti o pravidlách, ale praktické pravidlá stanovené na krúžku sa ukázali ako problém. Najmä akceptácia a neskákanie do reči, občas používanie nadávok a prezývok. Prežívanie nerešpektovania pravidiel počas samotného krúžku vyjadrovali participanti verbálne a často aj neverbálne.

S druhou otázkou súvisí aj téma OSR uprednostňovanie priatel'ských vztahov v triede a mimo nej. $\mathrm{V}$ tejto téme nachádzame prieniky aj s témou porozumenia sebe a druhým. Téma kamarátstva a otázky s ňou súvisiace sa objavili po čítaní príbehu Môžu byt také mäsiarky, ktoré chutia ako mrkva? a rovnako po prečítaní príbehu z románu Lukáš a Lenka.

V diskusii sa objavili problematika kamarátstva medzi triedami v škole a ukázalo sa, že počas školy sú triedy medzi sebou v nepriatel'skom vzt’ahu: „Sme nahnevaní, ako, tí béci sa so mnou prestanú kamarátit“ (A12583). „Áno. Kamarátili sa so mnou, hrali sa iba vtedy, ked” som mal cukríky“ (A12591). Béci - oni ako keby naschvál ich dali do tej béckej triedy a nás tých dobrých dali do tejto triedy, lebo oni sú takí, ktorí by sa predali za za, nechajú sa kúpit aj za jeden čips, a nás dali do takej triedy, kde sú ozajstní kamaráti. Ja ich volám bejci“ (A12622-12631).

Napriek tomu, že OSR neobsahuje problematiku spirituálnej výchovy, v diskusiách sa objavili aj témy viažuce sa na túto problematiku: .Po čítaní textu z knihy Blanka a Jirka, kde vo sne vystupovali rôzni bohovia, sa počas diskusie participant opýtal: „Ale ja by som chcel vediet, že ako sa ten Boh volá. Ten jeden, v prvom rade ja by som chcel, ktorý stvoril Adama a Evu, že ako sa volá ten Boh“(B30777-79).

Odpovede na tretiu výskumnú otázku sa vztahujú na postoje participantov k čítanému textu. Odpovede sa objavili aj spontánne, ale aj po kladení otázok, teda v tejto otázke nejde len o analýzu diskusií. Vel'mi často sa deti vyjadrovali k textu počas reflexie.

Mnohé postoje sme zaznamenali v kategórii Emócie. Po čítaní niektorých textov chceli realizovat aktivity, ktoré sa udiali v deji príbehu: „Budeme sa hrat’ aj my túto hru?“ (A6459). V prípade iného textu prejavil participant záujem o knihu, inokedy povedal, že napíše takýto príbeh sám a na úvod jedného z krúžkov povedal: „No tak ja som to niečo podobné napísal mame na meniny“ (B16039). Niektorí sa vyjadrili k textu hned”: „A to ste vy napísali tento príbeh? Páčil sa mi“ (A4002) na čo však d’alší participant zareagoval: „Ale bol taký pre dvojročné deti, pre škôlkarov“ (A 4009). V prípade iného textu sa participant vyjadril: „Ale to nie je vážny príbeh, to je len vymýšlanina nejaká, lebo Hitler nemohol mat’ dcéru, lebo by ju zavraždil“ (A9210). Počas jedného krúžku participant ukázal na knihu a povedal: „Možno, že ju dostanem na narodky. Ja som si ju vypýtal už na Vianoce“ (B17708-10).

Pri hodnotení krúžku sa participanti vyjadrovali aj k čítaniu: „Mala som sa dobre, lebo sme čítali a kreslili“ (A8400). „Ja som sa mala dobre, sa mi páčil príbeh...“ „Mal som sa dobre, lebo sme kreslili a čítali“ (B8276-8283). [Krúžok] „sa mi páčil vel’mi a hlavne kvôli tomu príbehu“ (B2387). „Mne sa páčil tento celý príbeh, celý krúžok“ (B2392).

K samotnému výberu textu sa objavili viaceré hodnotenia: Krúžok sa detom páčil, lebo „sme čítali detektívku...“ „...aj mne sa preto, pre tie detektívky sa mi to najviac páči“ (17639-17641). „Pri tých detektívoch sa učíme rozmýšlat najviac“ (B17649). „Výborné bolo čítanie detektívky“ (B17673). Na otázku, či chcú na d’alšom stretnutí čítat’ Blanka a Jirka alebo detektívky, odpovedali: „Detektívky,“ „Inšpektora,“ „Detektívne príbehy“ (B17720-17728). 


\section{Výsledky}

Všetky témy, ktoré sa vynorili jednak počas dialógov a jednak ktoré sa začali utvárat počas kódovania, súviseli s prečítanými príbehmi. Dialógy, ktoré sa viedli v skupine detí, odhalili kognitívnu a emocionálnu stránku a podporili behaviorálne prejavy.

Prvá otázka bola zameraná na zistenie, aký postoj zaujmú participanti k otázkam viažucim sa na ich osobný a sociálny rozvoj po prečitaní textu a následnej diskusii. Ukázalo a zároveň sa potvrdilo to, že deti si prinášajú postoje $\mathrm{z}$ rodinného prostredia a pri jednotlivých témach ich prezentujú. Avšak počas diskusií dochádzalo $\mathrm{k}$ istým posunom najmä v kognitívnej oblasti. Samotný text, ktorý sa čítal, často deti inšpiroval $\mathrm{k}$ uvádzaniu príkladov, argumentov, porovnaní aj k tvorbe dalších otázok počas diskusie.

Druhá otázka bola nasmerovaná na zmenu správania a prejavované emócie po prečítaní textu a následnej diskusii. Zaznamenali sme krátkodobé a individuálne zmeny v oblasti správania a prejavovania emócií. Z výsledkov tejto druhej otázky sa vynárajú nové otázky, ktoré by mohli byt predmetom dalších výskumov: Aký je vhodný text na filozofiu pre deti, aby zaujal všetkých členov skupiny (hladajúceho spoločenstva)? Ukázalo sa, že nie vždy boli všetky deti vtiahnuté do textu. Ďalšia otázka by mohla byt nasmerovaná na skladbu detí v skupine. Javí sa, že zaujatie pre text sa odvíja jednak od osobnostných kvalít, ale aj od vzájomných vztahov v skupine, ktoré niekedy poznačili proces čítania textu alebo jeho vnímania. Tieto zistenia sa do istej miery vztahujú aj na tretiu otázku.

Ak by sme dali prvú a druhú otázku do vztahu s uvedenými cielmi prierezovej témy Osobnostný a sociálny rozvoj, ukázalo sa, že deti rozumejú problematike vlastných kompetencií, práv a povinností a vedia ich odlišiti od toho, čo patrí dospelým. Dokážu posúdit aj to, na čo sú už dostatočne zrelí v porovnaní s mladšími detmi. Vedia sa vyjadrovat k otázke budúceho povolania, prejavit túžby a postoje. Rozumejú rozdielu pohlaví a čiastočne úlohe muža a ženy. Adekvátne veku dokážu hladat odpovede a argumenty v prospech svojich tvrdení. Do velkej miery sa počas aktivít odkrýval prirodzený potenciál rozumiet' sebe a iným. ${ }^{29}$ Témy jednotlivých príbehov a následne sformulované otázky a prebiehajúce diskusie boli z tohto hladiska podporné.

$\mathrm{Na}$ druhej strane sa ukázalo, že vedomie obmedzení a uvedomenie si neúspechu alebo nespokojnost's výkonom je prekážkou dalšej činnosti. Javí sa, že sebaobraz participantov odráža aj postoje rodičov alebo pedagógov a deti si ich zvnútorňujú. ${ }^{30}$ Týka sa to najmä morálnej a spirituálnej oblasti, ale aj postojov $\mathrm{k}$ sebe. $\mathrm{V}$ prítomnom okamihu sa ukazovalo nízka viera $\mathrm{v}$ to, že môžu dosiahnut zmenu, objavila sa nízka miera sebaúčinnosti, čo môže súvisiet jednak s problematikou sebaúcty, flexibility, ale aj s málo skúsenostami. ${ }^{31}$

Na kognitívnej úrovni ukázali deti pomerne vysokú mieru porozumenia sebe aj iným, no na druhej strane niektorým problémom nerozumejú. Týka sa to otázok, s ktorými nemajú skúsenost', a nových poznatkov, ktoré vybočujú z ich algoritmov chápania. Ide o výsledok prevzatých vzorcov uvažovania, postojov, ale aj návykov z rodinného prostredia, rovnako však to môže byt aj nízka miera kognitívnej empatie.

$\mathrm{Z}$ aspektu emocionality a správania sa ukázala vhodnost diskutovaných tém vyplývajúcich $z$ textu

29 Porov. Carl R. ROGERS, Být sám sebou, Praha: Portál, 2015; taktiež Martin E. P. SELIGMAN, Learned Optimism. How to Change Your Mind and Your Life, New York: Vintage Books, 2006.

30 Porov. Kristina R. OLSON - Carol Sorich DWECK, A Blueprint for Social Cognitive Development, Perspectives on Psychological Science 3/2008, s. 193-202.

31 Porov. Dale H. SCHUNK, Developing children's self-efficacy and skills: The roles of social comparative information and goal setting, Contemporary Educational Psychology 1/1983, s. 76-86. 
a následných aktivít. Ak sa detom darilo v aktivitách a v úlohách, na ktorých riešenie prišli, povzbudzovali a navádzali iných, aby sa dostali k riešeniu. Prejavovali radost’ z vlastného nápadu a zároveň podporovali druhých. Úspech a sprevádzajúce pozitívne prežívanie vytvárali dobrú klímu. Na druhej strane sa stávalo aj to, že ked' dokázali navrhovat riešenia alebo nejaký problém riešili s úspechom, radost’ prešla do spontánneho posúvania hraníc disciplinovanosti a porušovania pravidiel správania.

Participanti dokázali pomenovat’ svoje preživanie, ale problém bol usmerňovat' emócie a riešit problémy sprevádzané emóciami. Stávalo sa, že namiesto riešenia problémov zaujímali participanti obranné alebo impulzívne reakcie ako dôsledok toho, že t’ažko prijímali vinu alebo neúspech a rovnako aj potrebu (napr. kamaráta $\mathrm{v}$ skupine). ${ }^{32}$

Čo sa týka tretej otázky, a teda aký druh literatúry deti preferujú na tvorbu otázok na filozofické diskutovanie, napriek tomu, že sme overovali vhodnost’ textov na čítanie u rovesníkov ešte v predvýskume, nedá sa povedat', že by zaujali celú skupinu, skôr naopak, vnímali sme, že mnohé texty nie sú blízke bud' súčasným detom, alebo je problém v tom, že ide o prekladovú literatúru, ktorá je pôvodne určená čitatelom z iného kultúrneho prostredia. Deti najviac zaujala literatúra, ktorá bola sprevádzaná istým napätím, ale aj taká, ktorá silno pôsobila na prežívanie.

\section{Záver}

Vzhladom na to, že sa výskum realizoval počas vol’nočasových aktivít, deti mohli pracovat’ v ovela slobodnejšej a uvolnenejšej atmosfére, ako pracujú počas vyučovania v škole, ktorú navštevujú. Aj ich prejavy boli autentickejšie. Prejavili sa tak v oblasti kognitívnej, ako aj emocionálnej a behaviorálnej. Možností aplikácie prierezovej témy Osobnostný a sociálnych rozvoj je v tejto forme edukácie mnoho, realizácia metodiky FPD sa ukazuje ako vhodná.

Filozofické texty pre deti sa ukázali ako vhodné na tvorbu diskusných otázok a následné vyjadrovanie postojov spojených s osobnostným a sociálnym rozvojom.

Ako problematické sa ukazuje, že samotný text nemá až taký dosah na zmenu správania detí, skôr ho ovplyvňuje následná diskusia.

Na základe nášho výskumu sa ukazuje, že participanti mnoho vedia, dokážu si stát za niektorými postojmi a presvedčením. Výrazne sa prejavila dominancia kognitívnej stránky nad emocionálnou a behaviorálnou. Deti majú mnoho poznatkov, dokážu na svojej úrovni analyzovat, hodnotit, no majú problém spracovávat' emócie a usmerňovat’ správanie.

Vzhladom na čítané texty sa ukázalo, že nie všetky tituly boli vhodné. Pri vyjadreniach k literatúre sa explicitne nevyjadrili negatívne k žiadnemu titulu, v diskusiách však boli aj negatívne ohlasy. Javilo sa, že nie všetky texty sú pre deti pútavé.

Počas čítania sa javilo, že niektorý text participantov nebavil, záujem bolo potrebné vzbudzovat’ počas diskusie. K detektívnym príbehom sa negatívne nevyjadril nikto, naopak, pri možnosti vol'by boli všetci jednoznačne za detektívky.

Za pozornost' stojí uvažovat' nad vhodnostou čítaných textov. Matthew Lipman vytvoril texty, ktoré považoval za najvhodnejšie. Ako sám však uvádza, je potrebné čítat príbehy, ktoré sú blízke detom vzhladom na problémy, ktoré samy riešia. Vnímame, že takejto (didaktickej) literatúry je v našom prostredí málo, resp. žiadna. Prekladová literatúra určená na FPD, ktorú sme využili, sa však neukázala ako pútavá. Ak je literatúra vhodný nástroj na rozvoj multidimenzionálneho myslenia a osobnostný a sociálny rozvoj, je potrebné aj v slovenskom prostredí využit tie texty,

32 Porov. Anna BISSIOVÁ, Všemocné emoce? Jak poznat a zvládat vlastní emoce, Praha: Paulínky, 2014. 
ktorých problémy sú aktuálnymi problémami dnešných detí.

Ak chceme prehlbovat osobnostný a sociálny rozvoj, mali by byt texty obohatené práve o túto problematiku. Pôvodná literatúra je doplnená obsiahlymi metodickými príručkami. V prípade využitia vhodných slovenských textov alebo tvorby nových textov by bolo potrebné - vzhladom na ciele literatúry na filozofické diskutovanie s deṫmi - vytvorił aj metodické príručky k nim.

\section{Kontakt}

\section{PhDr. Gabriela Šarníková, PhD.}

Univerzita Palackého v Olomouci

Cyrilometodějská teologická fakulta

Katedra křestanské výchovy

Univerzitní 244/22, 77900 Olomouc

gabriela.sarnikova@upol.cz 